\title{
PENGGUNAAN CERITA ANAK SEBAGAI MEDIA PENINGKATAN KEMAMPUAN BERBAHASA INDONESIA SISWA KELAS 5 SEKOLAH DASAR
}

\author{
Dyah Werdiningsih \\ FKIP Universitas Islam Malang \\ e-mail: dyahwerdi@yahoo.co.id
}

\begin{abstract}
This study aimed to describe the use of children's stories as media to improve Indonesian language skills of Year 5 elementary school students. This study was an action research study employing the qualitative approach. The design was based on the procedure proposed by Kemmis and McTaggart (1988), consisting of plan, action, observation, and reflection. The subjects comprised teachers and students of SDN Gadang I Malang. The results showed that the learning model using children's stories in the Indonesian language learning was capable of improving Indonesian language skills of Year 5 elementary school students. This was shown by both their spoken and written performances.
\end{abstract}

Keywords: children's stories, learning media, Indonesian language skills

\section{PENDAHULUAN}

Di dalam Kebijakan Umum Pendidikan Dasar dan Menengah Kurikulum Berbasis Kompetensi dikemukakan bahwa kompetensi dasar yang diharapkan dimiliki oleh anak sekolah dasar (SD), diantaranya adalah kompetensi berpikir logis, kritis, kreatif, serta berkomunikasi lisan dan tulis melalui berbagai media termasuk teknologi informasi (Depdiknas, 2001). Kompetensi tersebut diharapkan dapat dikembangkan melalui pembelajaran bahasa dan Sastra Indonesia. Kompetensi yang dimaksud merupakan paduan dari dua subkompetensi yang tidak bisa dipisahkan, yaitu (1) kompetensi berpikir dan (2) kompetensi berbahasa. Hal ini sejalan dengan pernyataan Vygotsky (dalam Khasanah, 2002) bahwa bahasa berfungsi untuk mewadahi gagasan atau ide yang logis dan bahasa merupakan faktor utama yang menentukan perkembangan kognitif anak.

Sehubungan dengan hal tersebut, yang menjadi pertanyaan adalah apakah pembelajaran Bahasa dan Sastra Indonesia telah memberikan dukungan terhadap tercapainya penguasaan kompetensi bagi siswa SD? Berdasarkan pengamatan di lapangan, pelajaran Bahasa dan Sastra Indonesia masih belum dapat memberikan dukungan yang optimal terhadap pencapai kompetensi bagi siswa SD sebagaimana yang diharapkan. Pada umumnya, siswa kelas III SD belum memiliki kemampuan berbahasa, baik menyimak, berbicara, membaca, maupun menulis. Hal ini ditunjukkan dengan (1) lemahnya kemampuan siswa dalam menyimak pelajaran yang disampaikan oleh guru sehingga siswa tidak bisa menjawab beberapa pertanyaan yang dikemukakan oleh guru berdasarkan apa yang telah disampaikan, (2) lemahnya kemampuan siswa dalam berbicara sehingga mereka cenderung pasif, (3) lemahnya kemampuan siswa dalam membaca, baik dalam memahami bacaan dalam pelajaran Bahasa dan Sastra Indonesia maupun pelajaran lain, 
serta rendahnya tingkat pemahaman siswa terhadap isi soal-soal ujian dalam berbagai matapelajaran, dan (4) lemahnya kemampuan siswa dalam berkomunikasi secara tertulis yang tampak pada hasil tulisan siswa dan jawaban soalsoal ujian maupun latihan-latihan yang harus mereka kerjakan baik dalam mata pelajaran Bahasa dan Sastra Indonesia maupun matapelajaran yang lain.

Berdasarkan survai awal yang dilakukan dengan melakukan pengamatan di lapangan dan wawancara dengan beberapa guru Bahasa dan Sastra Indonesia serta wawancara dengan beberapa siswa SD, diperoleh gambaran faktor-faktor penyebab kekurangoptimalan pembelajaran Bahasa dan Sastra Indonesia dalam menumbuhkan keterampilan berbahasa siswa. Pertama, pembelajaran cenderung berorientasi pada pemberian pengetahuan tentang bahasa dan belum diorientasikan pada keterampilan berbahasa. Meskipun guru telah memahami pentingnya pemfokusan pembelajaran aspek keterampilan berbahasa, tetapi hingga saat ini masih mengalami kesulitan untuk memperbaharuhi pembelajaran di kelas mereka. Kedua, media pendukung pembelajaran masih sangat terbatas. Media pendukung yang dimaksud adalah media pembelajaran yang dapat digunakan untuk membangkitkan gairah belajar siswa. Ketiga, siswa kurang memiliki minat dan motivasi terhadap pelajaran Bahasa dan Sastra Indonesia, sehingga pembelajaran tidak dapat berlangsung dengan menyenangkan.

Berkaitan dengan tuntutan akan target penguasaan kompetensi bagi siswa SD dan beberapa kelemahan pelaksanaan pembelajaran Bahasa dan Sastra Indonesia di SD, maka cerita anak (CA) dipilih dan digunakan sebagai media pembelajaran kemampuan berbahasa. Pemilihan CA sebagai media pembelajaran kemampuan berbahasa ini dila- kukan berdasarkan pertimbangan-pertimbangan sebagai berikut. Pertama, CA diasumsikan memiliki sejumlah karakteristik yang mendukung terbentuknya kompetensi yang dimaksud. CA dapat mendukung perkembangan aspek afektif anak, yang meliputi perkembangan sosial-emosional, moral-sosial, dan bahasa anak (Galda, et al.,1993). Kedua, anak-anak usia SD lazimnya senang akan cerita (Huck, 1987; Purwo, 1991; dan Wollman-Bonila dan Werchadlo, 1995). Hal ini dapat dipahami karena anak-anak SD berada dalam taraf perkembangan kognitif, yaitu pada tingkatan operasi konkret dan operasi formal awal. CA dapat digunakan sebagai jembatan bagi anak-anak yang tengah bertransisi dari taraf operasi konkret ke taraf operasi formal. Ketiga, CA dapat digunakan sebagai dasar dalam program pembelajaran kemampuan berbahasa di SD. Salah satu program pemanfaatan cerita fiksi untuk pembelajaran kemampuan berbahasa adalah literature-based program dan literature-based instructional, yaitu praktik pembelajaran dan aktivitas belajar dengan menggunakan sastra anak sebagai dasar.

Penelitian yang dilakukan McGee dan Thompkins (1995) dan Dole et al. (1995) menunjukkan bahwa CA dapat dimanfaatkan untuk mengembangkan kemampuan membaca, memperkaya kosakata, dan mempercepat kemampuan berbicara secara signifikan. Demikian juga Scharer (1990) mengemukakan hasil penelitian mengenai keberhasilan guru SD dalam mengembangkan penggunaan sastra dalam pembelajaran kemampuan berbahasa di kelas. Keempat, CA memiliki keunikan yang mampu memikat hati anak-anak dan dapat dekat dengan realitas memenuhi rasa ingin tahu anak. Lebih dari itu, di dalam CA mengandung informasi yang kehidupan sehari-hari anak. Pertimbangan pemilihan CA sebagai media pembelajaran ke- 
mampuan berbahasa ini sangat relevan jika dikaitkan dengan gagasan Vigotsky bahwa anak dapat membentuksendiri kemampuan berpikir dan bahasanya melaluipenciptaan lingkungan belajar yang kontekstual. Oleh karena, CA menyediakan konteks yang dimaksud. Galda (1993) mengemukakan bahwa buku cerita yang bermutu dan berisi beragam struktur berguna bagi anak untuk belajar mengisahkan cerita, mengekspresikan emosi, serta menyajikan informasi. Pemajanan berbagai ragam buku CA yang bermutu akan membantu anak memahami teks-teks baru melalui skema yang terorganisasi.

Bertolak dari fakta mengenai pembelajaran kemampuan berbahasa di SD dan potensi CA sebagai media untuk mengembangkan kemampuan berbahasa Indonesia anak, penelitian ini dipandang perlu untuk dilakukan. Sesuai dengan pemikiran tersebut, fokus penelitian ini adalah pemanfaatan CA sebagai media pembelajaran untuk meningkatkan kemampuan berbahasa Indonesia di SD. Sejalan dengan fokus penelitian, tujuan penelitian ini adalah mengkaji penggunaan CA sebagai media untuk meningkatkan kemampuan berbahasa siswa kelas 5 SD.

Secara teoritis, hasil penelitian ini dapat memberikan sumbangan bagi pengembangan teori tentang program pembelajaran bahasa yang didasarkan pada cerita (literature-based program), yaitu praktik pembelajaran dan aktivitas belajar dengan menggunakan sastra anak sebagai dasar. Secara praktis, hasil penelitian ini dapat bermanfaat sebagai berikut. Pertama, bagi guru hasil penelitian ini dapat dijadikan sebagai rujukan dalam merencanakan, melaksanakan, dan mengevaluasi pembelajaran kemampuan berbahasa Indonesia di SD yang memanfaatkan ceria anak sebagai media. Lebih lanjut hasil penelitian ini dapat meningkatkan kinerja guru mela- lui perbaikan kualitas pembelajaran kemampuan berbahasa Indonesia. Kedua, bagi siswa, hasil penelitian ini dapat bermanfaat (1) meningkatkan kemampuan berbahasa Indonesia, (2) meningkatkan motivasi belajar, dan (3) melatih berpikir kritis dan belajar secara mandiri.

\section{METODE}

Penelitian ini merupakan penelitian tindakan. Dengan demikian, rancangan yang digunakan dalam penelitian ini adalah rancangan penelitian tindakan (McNiff, 1992). Pelaksanaan penelitian ini mengikuti prosedur penelitian tindakan menurut Kemmis dan McTaggart (1988) yang meliputi perencanaan, tindakan, pengamatan, dan refleksi. Prosedur tersebut dirinci sesuai dengan tahap-tahap penelitian tindakan yang dikemukakan Cohen dan Manion (dalam van Lier, 1989).

Prosedur perencanaan, tindakan, pengamatan, dan refleksi dirancang dengan mengikuti prosedur penelitian tindakan menurut Kemmis dan McTaggart (1988) dengan siklus yang membentuk lingkaran spiral. Dalam penelitian ini, siklus besar yang dilakukan sebanyak dua kali dalam satu semester. Setiap siklus besar terdiri atas tiga siklus kecil dengan lama waktu setiap siklus empat minggu kali empat jam pelajaran.

Penelitian tindakan kelas dilaksanakan di SDN Gadang I Malang. Subjek penelitian ini adalah guru dan siswa SDN Gadang I Malang. Pemilihan SD didasarkan pada kriteria (1) pengelolanya terbuka untuk inovasi, (2) guru kelas 5 bersedia diajak untuk berkolaborasi, dan (3) orangtua siswa mendukung kegiatan belajar di sekolah dan di rumah.

Studi awal yang dilakukan dalam penelitian ini meliputi tiga tahap. Pertama, studi awal dilakukan untuk mengkaji CA yang diminati anak dan 
potensial untuk dimanfaatkan sebagai media pembelajaran kemampuan berbahasa Indonesia anak. Kajian dilakukan dengan menelaah hasil-hasil penelitian dan teori tentang CA dengan karakteristik yang sesuai dengan teori pemerolehan bahasa. Kedua, mengkaji berbagai strategi pemanfaatan CA untuk pengembangan kemampuan berbahasa. Kajian dilakukan dengan menelaah hasil-hasil penelitian dan teori pemanfaatan CA dan strategi pemanfaatannya. Ketiga, mengkaji pelaksanaan pembelajaran kemampuan berbahasa Indonesia di kelas 5 SD yang diteliti untuk mengetahui strategi pembelajaran kemampuan berbahasa Indonesia yang digunakan guru di kelas 5 SD terteliti dan untuk mengetahui permasalahan yang dihadapi guru berkaitan dengan materi dan strategi pembelajaran kemampuan berbahasa Indonesia di kelas 5 SD.

Pelaksanaan tindakan dalam tiap siklus kecil dilakukan dengan langkah-langkah sebagai berikut. Pertama, pelaksanaan tindakan dalam siklus I dilakukan oleh peneliti sebagai model pelaksanaan tindakan pembelajaran kemampuan berbahasa berdasarkan CA, sementara guru berpartisipasi menjadi pengamat terlibat dan membantu pelaksanaan pembelajaran. Kedua, tindakan II dilakukan oleh guru kelas, peneliti berperan sebagai pendamping guru kelas terutama pada saat proses bejarmengajar. Ketiga, selama pelaksanaan tindakan peneliti dan guru kelas melakukan pengamatan terlibat dengan memanfaatkan instrumen pengumpul data. Selama tahap perencanaan, pelaksanaan tindakan, pengamatan, dan refleksi guru bertindak sebagai mitra kolaborasi.

Bentuk tindakan dalam penelitian ini adalah pembelajaran kemampuan berbahasa Indonesia berdasarkan CA. Oleh karena itu, rancangan tindakan pembelajaran dalam penelitian ini berupa rancangan tujuan, bahan, dan prosedur pembelajaran kemampuan berbahasa Indonesia berdasarkan CA untuk siswa kelas 5 SD difokuskan pada empat kemampuan berbahasa.

Pada tahap pengamatan dikumpulkan data dan informasi dari beberapa sumber sumber untuk mengetahui beberapa jauh efektivitas dari tindakan yang dilaksanakan. Pengamatan dilakukan untuk memperoleh berbagai data tentang sebagai berikut. Pertama, data tentang penguasaan kemampuan berbahasa Indonesia hasil pengamatan selama proses pembelajaran, hasil penyelesaian tugas, dan nilai ulangan harian. Kedua, data tentang antusias, aktivitas, dan pemilihan media diperoleh dari hasil observasi selama proses belajarmengajar oleh guru kolaborator. Keti$g a$, data tentang kegiatan siswa di luar kegiatan di kelas, seperti kapan siswa belajar, bermain dan dan lain-lain diperoleh melalui catatan harian guru dan cacatan aktivitas siswa di kelas selama pembelajaran.

Refleksi adalah kegiatan yang meluas secara kritis tentang perubahan yang terjadi pada siswa, suasana kelas dan guru. Semua subjek penelitian tindakan mendiskusikan hasil sebelum dan sesudah dilakukan tindakan (intervensi) kemudian merumuskan hasil tersebut, baik berupa keberhasilan maupun kekuarangannya untuk ditindaklanjuti dengan langkah-langkah penyempurnaan dan pengembangan. Dampak tindakan perbaikan dapat dilihat pada pengingkatan kemampuan berbahasa Indonesia, keantusiasan siswa dalam mengikuti pelajaran, dan keantusiasan siswa untuk mengerjakan tugas-tugas.

Dalam penelitian ini, data penelitian dibedakan menjadi dua, yaitu data awal dan data tindakan. Pertama, data awal berupa (1) karakteristik CA yang diminati anak-anak dan berpotensi untuk mengembangkan kemampuan berbahasa Indonesia siswa kelas 5 SD yang

Penggunaan Cerita Anak sebagai Media Peningkatan Kemampuan Berbahasa Indonesia 
bersumber dari paparan hasil-hasil penelitian dan teori tentang CA, serta teori pemerolehan bahasa; (2) strategi pembelajaran kemampuan berbahasa yang digunakan guru di kelas 5 SD terteliti yang bersumber dari interaksi belajarmengajar di kelas pembelajaran kemampuan berbahasa Indonesia siswa kelas 5 SD; dan (3) berbagai strategi pemanfaatan CA untuk mengembangkan kemampuan berbahasa, yang bersumber dari hasil penelitian dan teori tentang pemenfaatan CA serta strategi pemanfaatannya. Kedua, data tindakan mencakup data proses tindakan dan hasil tindakan. Data proses tindakan berupa data verbal lisan, respon verbal, tingkah laku subjek terteliti dan guru kelas 5 SD terteliti yang bersumber dari tampilan interaksi belajar-mengajar kemampuan berbahasa Indonesia. Data hasil tindakan berupa data verbal baik lisan maupun tulis yang bersumber dari tampilan verbal lisan dan tulisan siswa kelas 5 SD terteliti yang dikembangkan melalui pemanfaatan CA.

Dalam penelitian ini, peneliti bertindak sebagai instrumen kunci. Dalam mengumpulkan data, peneliti memanfaatkan catatan lapangan, catatan hasil wawancara, cacatan dokumen, dan sejumlah format pengumpul data. Untuk mengumpulkan data pelaksanaan dan hasil pembelajaran kemampuan berbahasa Indonesia siswa kelas 5 SD terteliti digunakan (1) format pengamatan prosedur dan interaksi dalam pembelajaran kemampuan berbahasa, (2) pedoman wawancara dengan siswa kelas 5 SD terteliti, guru kelas, dan orangtua siswa, dan (3) perangkat tes yang meliputi tes performansi berbahasa siswa, tes penguasaan isi mata pelajaran yang lain.

Pengumpulan data awal dilakukan dengan (1) membaca teori dan hasil penelitian tentang CA yang berpotensi mengembangkan bahasa anak, kurikulum, dan teori pemanfaatan CA untuk pembelajaran kemampuan berbahasa, (2) melakukankan wawancara dengan guru dan siswa, serta melakukan pengamatan di kelas untuk mengetahui pelaksanaan pembelajaran kemampuan berbahasa Indonesia di kelas 5 SD terteliti.

Adapun pengumpulan data tindakan dan hasil tindakan dilakukan dengan mengamati, merekam, mencatat tuturan verbal lisan, respon verbal, tingkah laku subjek terteliti dan guru dan siswa kelas 5 SD terteliti yang bersumber dari tampilan interaksi belajar-mengajar kemampuan berbahasa Indonesia. Sedangkan pengumpulan data hasil tindakan dilakukan dengan merekam tuturan baik lisan maupun tulis yang bersumber dari tampilan verbal lisan dan tulisan siswa kelas 5 SD terteliti.

Analisis data dalam penelitian ini menganut prinsip multiguna dengan tujuan bagaimana suatu teknik analisis dapat digunakan untuk mendukung pemecahan masalah yang telah dirumuskan (McNiff, 1992). Data dalam penelitian ini dengan teknik analisis data model alir (Miles dan Huberman, 1990). Penyimpulan dilakukan setelah kegiatan reduksi dan penyajian data. Simpulan pertama, kedua, dan ketiga diverifikasi melalui diskusi dengan guru kolaborator dan teman sejawat.

Untuk mempermudah analisis data berkaitan dengan proses pembelajaran kemampuan berbahasa Indonesia berdasarkan CA digunakan indikator keberhasilan proses pembelajaran dan hasil belajar. Rambu-rambu proses pembelajaran dikembangkan dari tahap-tahap dalam prosedur pembelajaran kemampuan berbahasa Indonesia berdasarkan CA dengan prosedur (1) fokus pembelajaran, (2) penentuan indikator pembelajaran, dan (3) penentuan kualifikasi. Adapun rambu-rambu hasil belajar disusun berdasarkan butir-butir hasil belajar yang menjadi fokus dalam 
penelitian ini dengan prosedur (1) penentuan indikator hasil belajar, (2) penentuan ciri deskriptor, dan (3) penentuan kualifikasi hasil.

Indikator keberhasilan penelitian ini ditunjukkan dengan beberapa hal berikut, yaitu (1) terdapat peningkatan prestasi belajar sekurang-kurangnya $80 \%$ siswa mendapat nilai ulangan harian 70; (2) sekurang-kurangnya 75\% siswa termotivasi dalam pembelajaran kemampuan berbahasa Indonesia berdasarkan CA, dan (3) terdapat peningkatan kinerja guru dalam proses belajarmengajar dengan menerapkan pembelajaran kemampuan berbahasa Indonesia berdasarkan CA.

\section{HASIL DAN PEMBAHASAN Hasil dan Pembahasan Siklus I}

Data dan temuan hasil PTK siklus 1 disajikan berdasarkan hasil pengamatan, perekaman dan catatan lapangan aktivitas guru dan siswa, wawancara, dokumentasi rencana pembelajaran dan hasil kerja siswa. Agar diperoleh gambaran yang sistematis dan menyeluruh, paparan dimulai dari penggambaran perencanaan pembelajaran, pelaksanaan pembelajaran, evaluasi pembelajaran, temuan, dan refleksi tindakan.

\section{Perencanaan Pembelajaran Siklus I}

Perencanaan pembelajaran siklus 1 direncanakan berdasarkan hasil studi pendahuluan yang telah dilakukan peneliti pada bulan April 2006 di SDN Gadang I Malang. Studi pendahuluan dilakukan sebelum tindakan dilakukan melalui pengamatan dan daftar pertanyaan kepada siswa dan guru. Pengamatan dilakukan sewaktu guru mengajar BI di kelas. Pengamatan tersebut meliputi perencanaan pembelajaran, aktivitas siswa di kelas, cara guru mengajar, respon siswa, interaksi gurusiswa, dan hasil pembelajaran siswa.
Pertanyaan untuk siswa meliputi pemahaman siswa mengenai pembelajaran BI, minat siswa, cara guru mengajarkan, motivasi siswa dalam belajar, dan tindak lanjut setelah pembelajaran menulis laporan. Pertanyaan untuk guru meliputi pemahaman guru tentang materi yang diajarkan, respon siswa terhadap pembelajaran BI yang telah dilakukan, kendala-kendala yang dihadapi dalam pembelajaran BI, evaluasi pembelajaran BI, dan pemanfaatan cerita anak.

Dari hasil pengamatan dan pertanyaan diperoleh gambaran bahwa persiapan yang dilakukan dalam pembelajaran BI adalah siswa kurang dikondisikan terlebih dahulu. Sebelum siswa mengikuti pembelajaran sastra tidak ada informasi awal apakah nantinya akan dinilai kemampuan berbahasa Indonesianya. Dengan tidak diberitahukan tugas tersebut, mengakibatkan siswa tidak memperhatikan ketepatan penggunan BI dalam menjawab pertanyaan-pertanyaan setelah membaca teks sastra dan menulis tugas-tugas yang terkait dengan pembelajaran sastra di kelas.

Pelaksanaan pengajaran BI dilakukan dengan teknik ceramah dan pemberian tugas. Guru tidak memberi tugas-tugas yang dapat mendorong aktivitas siswa dalam proses pembelajaran, Proses pembelajaran kurang menarik dan tidak memanfaatkan mediaHal ini menyebabkan motivasi belajar BI siswa rendah, siswa cepat bosan dalam memperhatikan pelajaran, kemudian ngobrol dengan teman duduknya, dan siswa lebih menyukai buku cerita daripada buku pelajaran. Di sisi lain diketahui bahwa strategi pemanfaatan cerita anak berpotensi untuk pengembangan kemampuan berbahasa. Ketersediaan media ceria anak ini didukung oleh orangtua siswa.

Pertemuan ketiga dilakukan penyusunan skenario pembelajaran yang direncanakan sebagai berikut (1) mem- 
bangkitkan skemata siswa dengan mengajukan pertanyaan yang berkaitan manfaat CA, (2) menjelaskan kegiatan pembelajaran, (3) mengorganisasikan kelas, (4) meminta siswa secara kelompok membaca CA yang telah dibagikan, (5) meminta siswa (a) praktik menjawab pertanyaan dan mengemukakan secara lisan dengan menceritakan tokoh, latar, penyajian alur cerita-cerita, dan menuturkan cerita, (b) secara tertulis untuk mengidentifikasi fakta dalam cerita, menebak lanjutan cerita, dan mengidentifikasi peristiwa penting, dan siswa diarahkan untuk menuliskan kembali CA yang dibacanya dan menulis cerita baru. Peneliti dan guru BI membuat perencanaan pembelajaran menulis laporan teknik dengan strategi pemodelan pada siklus 2 secara kolaboratif. Penyajian perencanaan pembelajaran ini membutuhkan waktu 2 kali pertemuan (pertemuan masing-masing 2x45 menit.

Rencana hasil belajar yang dicapai adalah siswa dapat menceritakan kembali CA. Rencana indikator yang hendak dicapai pada tahap persiapan membaca CA adalah siswa dapat (1) menjawab pertanyaan dan mengemukakan secara lisan dengan menceritakan tokoh, latar, penyajian alur cerita-cerita, dan menuturkan cerita dan (2) mengidentifikasi fakta dalam cerita, menebak lanjutan cerita, dan mengidentifikasi peristiwa penting, dan siswa diarahkan untuk menuliskan kembali CA yang dibacanya dan menulis cerita baru.

Rencana skenario pembelajaran pada tahap persiapan menulis laporan adalah (1) mengorganisasikan kelas dengan tindakan (a) membagi siswa menjadi 9 kelompok yang tiap kelompok beranggotakan 5 siswa, (c) membacakan keanggotaan kelompok, (d) mengatur tugas siswa sesuai dengan anggota kelompok, (2) membangkitkan skemata siswa dengan mengajukan pertanyaan yang berkaitan dengan CA yang di- baca, (3) menjelaskan kompetensi yang dicapai siswa dalam pembelajaran, (c) meminta tanggapan siswa tentang kompetensi yang dicapai, (d) memotivasi siswa, (4) tindakan: (a) menjelaskan kegiatan yang akan dilakukan, (b) meminta siswa menceritakan tokoh, latar, penyajian alur cerita-cerita, dan menuturkan cerita, dan (c) meminta siswa mengidentifikasi fakta dalam cerita, menebak lanjutan cerita, dan mengidentifikasi peristiwa penting, dan siswa diarahkan untuk menuliskan kembali CA yang dibacanya dan menulis cerita baru, (5) pengumpulan data dengan tindakan, dan (6) merefleksi terhadap proses dan hasil belajar dengan menanyakan kelengkapan data.

Rencana skenario pembelajaran (1) mengorganisasikan kelas dengan mengatur posisi duduk siswa sesuai dengan kelompok, (2) membangkitkan skemata siswa dengan tindakan (a) menanyakan hasil pembacaan CA, (b) menanyakan hasil identifikasi CA, dan (c) memotivasi siswa, (3) menyusun kerangka laporan dengan tindakan dan (4) mengadakan refleksi terhadap proses dan hasil belajar.

Penilaian hasil dilakukan setelah pada saat siswa (1) mengemukakan secara lisan dengan hasil identifikasi karakter tokoh, latar, penyajian alur cerita-cerita, dan menuturkan cerita dan (2) mengemukakan secara tertulis hasil identifikasi fakta dalam cerita, menebak lanjutan cerita, dan mengidentifikasi peristiwa penting, dan siswa diarahkan untuk menuliskan kembali CA yang dibacanya dan menulis cerita baru.

\section{Pelaksanaan Pembelajaran Siklus 1}

Pelaksanaan pembelajaran peningkatan kemampuan berbahasa melalui pemanfaatan CA, dibagi dua tahap, yakni (1) mengemukakan secara lisan dengan hasil identifikasi karakter tokoh, latar, penyajian alur cerita-cerita, dan 
menuturkan cerita dan (2) mengemukakan secara tertulis hasil identifikasi fakta dalam cerita, menebak lanjutan cerita, dan mengidentifikasi peristiwa penting, dan siswa diarahkan untuk menuliskan kembali CA yang dibacanya dan menulis cerita baru.

Guru kejuruan memulai kegiatan dengan menjelaskan kegiatan pembelajaran yang akan dilaksanakan dan siswa memberikan tanggapan siswa positif, mereka senang belajar bahasa dengan membaca CA. Kegiatan dilanjutkan dengan penjelasan kompetensi yang dicapai siswa dan meminta siswa menanggapi. Tanggapan siswa beragam, sebagian besar siswa menghendaki tugas dikerjakan di rumah. Kemudian, guru memotivasi siswa dan menjelaskan perlunya pengerjaan tugas secara kelompok di dalam kelas.

Kegiatan selanjutnya, guru menjelaskan kegiatan pembelajaran yang akan dilaksanakan. Mula-mula guru BI menjelaskan kompetensi yang dicapai siswa kemudian menuliskan kompetensi tersebut di papan tulis. Kompetensi yang harus dikuasai siswa adalah siswa mampu (1) mengemukakan secara lisan dengan hasil identifikasi karakter tokoh, latar, penyajian alur cerita-cerita, dan menuturkan cerita dan (2) mengemukakan secara tertulis hasil identifikasi fakta dalam cerita, menebak lanjutan cerita, dan mengidentifikasi peristiwa penting, dan siswa diarahkan untuk menuliskan kembali CA yang dibacanya dan menulis cerita baru.

Rencana skenario pembelajaran pada tahap persiapan menulis laporan adalah (1) mengorganisasikan kelas dengan tindakan (a) membagi siswa menjadi 9 kelompok yang tiap kelompok beranggotakan 5 siswa, (c) membacakan keanggotaan kelompok, (d) mengatur tugas siswa sesuai dengan anggota kelompok, (2) membangkitkan skemata siswa dengan mengajukan pertanyaan yang berkaitan dengan CA yang dibaca, (3) menjelaskan kompetensi yang dicapai siswa dalam pembelajaran, (c) meminta tanggapan siswa tentang kompetensi yang dicapai, (d) memotivasi siswa, (4) tindakan: (a) menjelaskan kegiatan yang akan dilakukan, (b) meminta siswa membaca CA, (b) meminta siswa menceritakan tokoh, latar, penyajian alur cerita-cerita, dan menuturkan cerita, dan (c) meminta siswa mengidentifikasi fakta dalam cerita, menebak lanjutan cerita, dan mengidentifikasi peristiwa penting, dan siswa diarahkan untuk menuliskan kembali CA yang dibacanya dan menulis cerita baru, (5) pengumpulan data dengan tindakan, dan (6) merefleksi terhadap proses dan hasil belajar dengan menanyakan kelengkapan data.

Rencana skenario pembelajaran (1) mengorganisasikan kelas dengan mengatur posisi duduk siswa sesuai dengan kelompok, (2) membangkitkan skemata siswa dengan tindakan (a) menanyakan hasil pembacaan CA, (b) menanyakan hasil identifikasi CA, dan (c) memotivasi siswa, (3) menyusun kerangka laporan dengan tindakan dan (4) mengadakan refleksi terhadap proses dan hasil belajar.

\section{Hasil Pengamatan Siklus I}

Dari hasil pengamatan yang dilakukan oleh dua peneliti pada siklus I ini terdapat beberapa hal yang bersifat positif dan hal-hal yang bersifat negatif. Hal hal yang bersifat negatif akan diperbaiki pada siklus II.

Dari pengamatan selama siklus pertama diketahui bahwa dalam proses belajar mengajar dengan memanfaatkan media CA, siswa nampak antusias dan senang ketika belajar sambil mendengarkan cerita atau membaca cerita yang disuguhkan kepadanya. Hal itu tampak dari keikutsertaan siswa menyimak dan membaca dengan antusias. Dengan demikian, secara tidak langsung mereka 
bisa meningkatkan partisipasinya dalam kegiatan belajar. Hal ini didukung dari hasil tanya-jawab dengan beberapa siswa yang menyatakan bahwa mereka senang belajar BI dengan cara ini.

Akan tetapi untuk siklus I ini banyak hal negatif yang ditemukan. Halhal negatif itu adalah sebagai berikut (1) jumlah siswa kelas 5 yang besar yaitu 46 siswa, (2) jumlah pembacaan cerita mencapai 3 kali karena mereka masih meresa sangat sulit memahami teks cerita tersebut, (3) banyak siswa yang belum bisa mengidentifikasi karakter tokoh, latar, dan alur serita, dan (4) ketika mereka diminta untuk menceritakan kembali teks dengan bebas secara lisan dalam bahasa Indonesia, mereka belum bisa mengemukakan dengan jelas dan runtut, demikian juga ketika menuliskannya.

Selanjutnya, sesuai dengan tujuan penelitian ini yaitu apakah pembelajaran kemampuan BI melalui pemanfaatan media CA bisa meningkatkan keterampilan, mendengar, berbicara, membaca dan menulis pada hasil temuan kemampuan BI dari siklus ke I, hal ini dikemukan sebagai berikut. Pengajaran bahasa Inggris melalui pemanfaatan media CA memimiliki dampak besar pada keterampilan memahami bacaan, akan tetapi belum berdampak positif pada keterampilan berbicara dan menulis. Hal-hal yang menyebabkan keterampilan mereka belum baik pada keterampilan berbicara maupun menulis adalah disebabkan oleh jumlah siswa dalam kelas yang sangat besar untuk belajar keterampilan berbicara, sedangkan untuk keterampilan menulis kelemahan ini sudah menjadi masalah umum dan dikaui oleh para praktisi pengajar karena menulis adalah keterampilan yang paling sulit. Akhirnya, untuk keterampilan mendengar siswa masih memperoleh nilai belum maksimal karena disebabkan oleh tidak lancarnya praktik berbicara oleh siswa.

\section{Hasil dan Pembahasan Siklus 2}

Data dan temuan hasil PTK siklus 2 disajikan berdasarkan hasil pengamatan, perekaman dan catatan lapangan aktivitas guru dan siswa, wawancara, dokumentasi rencana pembelajaran dan hasil kerja siswa. Agar diperoleh gambaran yang sistematis dan menyeluruh, paparan dimulai dari penggambaran perencanaan pembelajaran, pelaksanaan pembelajaran, evaluasi pembelajaran, temuan, dan refleksi tindakan.

\section{Perencanaan Pembelajaran Siklus 2}

Peneliti dan guru BI membuat perencanaan pembelajaran menulis laporan teknik dengan strategi pemodelan pada siklus 2 secara kolaboratif. Penyajian perencanaan pembelajaran ini membutuhkan waktu 2 kali pertemuan (pertemuan masing-masing 2x45 menit.

Rencana hasil belajar yang dicapai adalah siswa dapat menceritakan kembali CA. Rencana indikator yang hendak dicapai pada tahap persiapan membaca CA adalah siswa dapat (1) menjawab pertanyaan dan mengemukakan secara lisan dengan menceritakan tokoh, latar, penyajian alur cerita-cerita, dan menuturkan cerita dan (2) mengidentifikasi fakta dalam cerita, menebak lanjutan cerita, dan mengidentifikasi peristiwa penting, dan siswa diarahkan untuk menuliskan kembali CA yang dibacanya dan menulis cerita baru.

Rencana skenario pembelajaran pada tahap persiapan menulis laporan adalah (1) mengorganisasikan kelas dengan tindakan (a) membagi siswa menjadi 9 kelompok yang tiap kelompok beranggotakan 5 siswa, (c) membacakan keanggotaan kelompok, (d) mengatur tugas siswa sesuai dengan anggota kelompok, (2) membangkitkan skemata siswa dengan mengajukan pertanyaan yang berkaitan dengan CA yang dibaca, (3) menjelaskan kompetensi yang 
dicapai siswa dalam pembelajaran, (c) meminta tanggapan siswa tentang kompetensi yang dicapai, (d) memotivasi siswa, (4) tindakan: (a) menjelaskan kegiatan yang akan dilakukan, (b) meminta siswa menceritakan tokoh, latar, penyajian alur cerita-cerita, dan menuturkan cerita, dan (c) meminta siswa mengidentifikasi fakta dalam cerita, menebak lanjutan cerita, dan mengidentifikasi peristiwa penting, dan siswa diarahkan untuk menuliskan kembali CA yang dibacanya dan menulis cerita baru, (5) pengumpulan data dengan tindakan, dan (6) merefleksi terhadap proses dan hasil belajar dengan menanyakan kelengkapan data.

Rencana skenario pembelajaran (1) mengorganisasikan kelas dengan mengatur posisi duduk siswa sesuai dengan kelompok, (2) membangkitkan skemata siswa dengan tindakan (a) menanyakan hasil pembacaan CA, (b) menanyakan hasil identifikasi CA, dan (c) memotivasi siswa, (3) menyusun kerangka laporan dengan tindakan dan (4) mengadakan refleksi terhadap proses dan hasil belajar.

Penilaian hasil dilakukan setelah pada saat siswa (1) mengemukakan secara lisan dengan hasil identifikasi karakter tokoh, latar, penyajian alur cerita-cerita, dan menuturkan cerita dan (2) mengemukakan secara tertulis hasil identifikasi fakta dalam cerita, menebak lanjutan cerita, dan mengidentifikasi peristiwa penting, dan siswa diarahkan untuk menuliskan kembali CA yang dibacanya dan menulis cerita baru.

\section{Pelaksanaan Pembelajaran Siklus 2}

Pelaksanaan pembelajaran peningkatan kemampuan berbahasa melalui pemanfaatan CA, dibagi dua tahap, yakni (1) mengemukakan secara lisan dengan hasil identifikasi karakter tokoh, latar, penyajian alur cerita-cerita, dan menuturkan cerita dan (2) mengemuka- kan secara tertulis hasil identifikasi fakta dalam cerita, menebak lanjutan cerita, dan mengidentifikasi peristiwa penting, dan siswa diarahkan untuk menuliskan kembali CA yang dibacanya dan menulis cerita baru.

Guru kejuruan memulai kegiatan dengan menjelaskan kegiatan pembelajaran yang akan dilaksanakan, bahwa pembelajaran hari ini digabungkan dengan pembelajaran BI. Tanggapan siswa positif, mereka senang belajar bahasa dengan membaca CA. Kegiatan dilanjutkan dengan penjelasan kompetensi yang dicapai siswa dan meminta siswa menanggapi. Tanggapan siswa beragam, sebagian besar siswa menghendaki tugas dikerjakan di rumah. Kemudian, guru memotivasi siswa dan menjelaskan perlunya pengerjaan tugas secara kelompok di dalam kelas.

Kegiatan selanjutnya, guru mengorganisasikan kelas dengan membagi siswa menjadi 8 kelompok yang masing-masing kelompok beranggotakan 5 siswa kemudian membacakan anggota kelompok dan mengatur tugas siswa. Pembagian kelompok ini didasarkan hasil pengamatan keaktifan siswa dan penilaian performansi siswa pada siklus pertama. Pembagian kelompok ini bertujuan agar terjadi pemerataan kemampuan siswa dalam menulis laporan sehingga siswa terlihat aktif. Mereka saling mencari anggota kelompok masingmasing dan menunjuk ketua kelompok.

Kegiatan selanjutnya, guru menjelaskan kegiatan pembelajaran yang akan dilaksanakan. Mula-mula guru BI menjelaskan kompetensi yang dicapai siswa kemudian menuliskan kompetensi tersebut di papan tulis. Kompetensi yang harus dikuasai siswa adalah siswa mampu (1) mengemukakan secara lisan dengan hasil identifikasi karakter tokoh, latar, penyajian alur cerita-cerita, dan menuturkan cerita dan (2) mengemukakan secara tertulis hasil identifikasi fak-

Penggunaan Cerita Anak sebagai Media Peningkatan Kemampuan Berbahasa Indonesia 
ta dalam cerita, menebak lanjutan cerita, dan mengidentifikasi peristiwa penting, dan siswa diarahkan untuk menuliskan kembali CA yang dibacanya dan menulis cerita baru.

\section{Hasil Pengamatan Siklus II}

Dari hasil pengamatan yang dilakukan oleh dua peneliti pada siklus II beberapa hal yang bersifat bersifat postif terus dijaga dan hal-hal yang negatif pada siklus I telah direvisi dan hal itu membuahkan perubahan pada performansi berbahasa Indonesia siswa dalam proses pembelajaran.

Pada siklus II, siswa dibagi kelompok dengan anggota lima orang perkelompok. Sebelum tatap muka berlangsung, guru menugasi siswa untuk menyiapkan dan membaca CA yang sama tiap kelompok. Dengan demikian, siswa lebih siap untuk mengikuti pembelajaran dibandingkan dengan pada siklus I, yakni tugas membaca dilakukan kelas setelah CA dibagikan pada tatap muka itu juga. Dengan cara ini siswa nampak lebih antusias dan lebih siap untuk berpartisiasi dalam proses pembelajaran di kelas.

Kelemahan pada siklus I yaitu jumlah siswa kelas 5 yang besar yaitu 46 siswa dapat diatasi pengelolaannya dengan membagi siswa dalam kelompok yang beranggotakan lima orang. Jumlah pembacaan cerita cukup dilakukan satu kali, bahkan sebagian mereka yang tidak membaca di kelas karena sudah membaca di rumah, sehingga mereka dapat langsung mempersiapkan jawaban beberapa tugas yang diberikan. Siswa semakin jeli dan tajam dalam melakukan mengidentifikasi karakter tokoh, latar, dan alur cerita. Performansi mereka untuk menceritakan kembali teks dengan bahasa bebas secara lisan dalam BI telah mengalami kemajuan. Hal itu ditunjukkan dengan kejelasan dan keruntutan uraian mereka.
Terlalu seringnya mereka, siswa, meminta guru untuk memutarkan lagu sampai sampai 6 kali pada siklus ke II ini telah menunjukkan perubahan yang lebih baik. Hasil pengamatan dari dua lagu yang liriknya lebih pendek, siswa hanya butuh mendengar lagu-lagu tesebut hanya sampai 3 kali. Hal ini menunjukkan adanya peningkatan kemampuan atau kompetensi mendengar (listening) siswa meningkat lebih terampil. Di sisi lain guru lebih bisa menguasai kelas karena suara guru bisa ditangkap dengan jelas oleh siswa yang duduk di belakang. Dengan model penglompokan siswa melalui berhitung angka dalam bahasa Inggris siswa lebih cepat membentuk kelompok secara otomatis dan cepat mencari anggota kelompoknya. Demikian juga, ketika diminta menuliskan kembali isi cerita dengan bahasa mereka sendiri. Anak mampu mengemukakan isi cerita dengan lebih baik. Hal ini ditunjukkan dengan adanya kejelasan, keruntutan, dan keutuhan cerita yang dikemukakan sesuai dengan keruntutan alur dan keutuhan CA yang dibaca oleh anak.

Dari hasil pengamatan terhadap performansi berbahasa lisan dan tulis siswa dapat diketahui bahwa pembelajaran BI dengan memanfaatkan CA mampu meningkatkan kompetensi berbahasa mereka. Dari semua keterampilan berbahasa, hanya keterampilan menyimak saja yang didak teramati hasil peningkatannya karena jam pelajaran tidak cukup untuk meminta siswa mengemukakan hasil penyimakan mereka terhadap penampilan antarkelompok. Selain itu, pemamfaatan media CA dapat mendukung penciptaan suasana belajar atau susana kelas menjadi menyenangkan dan tidak tegang sehingga memotivasi mereka untuk berpartisipasi selama proses belajar- mengajar.

Dengan pemanfaatan CA ini, siswa merasa memperoleh manfaat 
dan menemukan hal baru dalam proses pembelajaran sesuai dengan fungsi bahasa sebagai sarana komunikasi antara siswa dengan siswa dan siswa dengan guru. Salah satu situasi baru yang dapat diterapkan adalah dengan penggunaan lagu sebagai media pembelajaran dalam kelas pembelajaran yang menyenangkan memang disyaratkan oleh kurikulum baru tahun 2004 .

Pembelajaran BI melalui pemanfaatan CA terbukti dapat meningkatkan minat siswa dan mendorong partisipasi aktif siswa menjadi lebih baik. CA yang dibaca anak ini sekaligus merupakan sumber belajar tentang penggunaan BI yang autentik sehingga lebih bermakna bagi siswa. Selain itu, langkah ini dapat mendekatan siswa dengan karya sastra sehingga mereka dapat belajar berbagai nilai kehidupan yang dapat menjadi bekal dalam hidupnya kelak kemudian hari. Hal dapat berdampak positif bagi peningkatan apresiasi sastra mereka. Lebih dari itu, kegiatan ini dapat meningkatkan minat baca siswa serta meningkatan kemampuan kritis mereka dalam melakukan pengkajian terhadap teks bacaan.

Dampak positif pemanfaatan media pembelajaran ini ditegaskan oleh Regina dan Fai (1998) yang menyatakan bahwa media pembelajaran merupakan sarana yang sangat bermanfaat guna mengembangkan kemampuan siswa dalam mendengar, berbicara, membaca, menulis dan bisa juga digunakan untuk mengajar komponen bahasa seperti, kosa kata, struktur kalimat, dan pengucapan bahasa. Dari penelitian yang mereka lakukan kepada siswa tingkat menengah, dapat dilihat bahwa siswa sangat tertarik dan antusias terhadap pelajaran BI dan meningkatkan tingkat keterlibatan mereka dalam interaksi dalam kelas. Gebhard (1996) juga mengatakan bahwa sebagian besar orang akan setuju dengan pembelajaran lewat CA sehingga murid dapat mengerti tentang cerita tersebut. Senada dengan pendapat tersebut, Finocchiaro dan Brumfit (1983) mengemukakan bahwa pembelajaran melalui CA dapat digunakan pada pelajaran ekstensif maupun intensif. Dengan memanfaatkan media tersebut akan terciptan suasana yang menggembirakan dan menyenangkan selain juga siswa memperoleh peningkatan kemampuan berbahasa mereka.

\section{SIMPULAN}

Berdasarkan hasil analisis data, simpulan penelitian ini dapat dipaparkan sebagai berikut. Secara umum, hasil penelitian menunjukkan bahwa model pembelajaran melalui pemanfaatan CA dalam pembelajaran BI dapat meningkatkan kemampuan BI siswa kelas 5 SD. Hal ini ditunjukkan dengan peningkatan performansi siswa baik dalam berbahasa lisan maupun tulis. Secara rinci simpulan penelitian ini dikemukakan sebagai berikut: (1) model pembelajaran melalui pemanfaatan CA ini meningkatkan kompetensi mendengarkan siswa, yang ditunjukkan dari frekuensi pembacaan CA 2-3 kali menjadi cukup satu kali, (2) model pembelajaran melalui pemanfaatan CA ini meningkatkan kompetensi membaca siswa yang ditujukkan dengan ketepatan siswa dalam menjawab pertanyaan sesuai dengan isi bacaan, (3) model pembelajaran melalui pemanfaatan CA ini meningkatkan kompetensi berbicara secara sangat signifikan yang ditunjukkan dengan Anak mampu mengemukakan isi cerita dengan lebih baik, dan (4) model pembelajaran melalui pemanfaatan CA ini meningkatkan kompetensi menulis secara sangat signifikan yang ditunjukkan dengan adanya kejelasan, keruntutan, dan keutuhan cerita yang dikemukakan sesuai dengan keruntutan alur dan keu- 
tuhan CA yang dibaca oleh anak ketika diminta untuk menceritakan kembali isi cerita secara tertulis.

\section{UCAPAN TRIMA KASIH}

Ucapan terima kasih disampaikan kepada Bapak/Ibu dan para murid kelas V SD Negeri Gadang 1 Malang yang telah membantu pelaksanaan penelitian. Selanjutnya ucapan terima kasih disampaikan kepada rekan sejawat yang telah membantu kegiatan verifikasi dan triangulasi data dan interpertasi, serta kepada reviewer anonim yang telah membaca, mengoreksi dan memberi masukan terhadap artikel ini.

\section{DAFTAR PUSTAKA}

Baker, A. \& Johny. 1994. Developing Thinking Skills, Using Children's Literature. Eleanor Curtain Publishing.

Christantiowati. 1996. Bacaan Anak Indonesia Tempo Doeloe, Kajian Pendahuluan Periode 1908-1945. Jakarta: Balai Pustaka.

Depdikbud, 1993. Kurikulum Pendidikan Dasar. Jakarta: Depdikbud.

Finocchiaro\& Brumfit. 1983. The Notional -Functional Approach: From Theory to Practice. Oxford: Oxford University Press.
Finocchiaro. 1989. Teaching English as a Second Language. New Jersey: Prentice Hall Regent, Englewood Cliff.

Gebhard, Jerry G. 1996. Teaching English as a Foreign or Second Language: A Teacher Self-development and Methodology Guide. Michigan: The University of Michigan Press.

Pepak. 2003. Literatur untuk Anak. Yayasan Lembaga Sabda.e-BinaAnak/ e-BinaGuru. 4 Maret 2003.

Putra, R.M.S. 2003. "Impact of Comics and Other Kinds of New Media on Children's in Indonesia". $A B D$ Volume 30. No. 2. EDRS's web site

Lo, Regina dan Henry Chi Fai Li. 1998. "Songs Enhance Learner Involvement; Materials Development" dalam Forum vol.36 Juli-September 1998.

Sudarman, Sri dan Roekhan. 1995. "Membaca Sebagai Tindak Mawas Diri". Dalam Bahasa dan Sastra Indonesia. 1 (1) hlm. 83--92.

Suyitno. 1986. Sastra, Tata Nilai, dan Eksegesis. Yogyakarta: Hanindita.

McTaggart, Robin. 1991. Action Research: A Short Modern History. Victoria: Deakin University. 